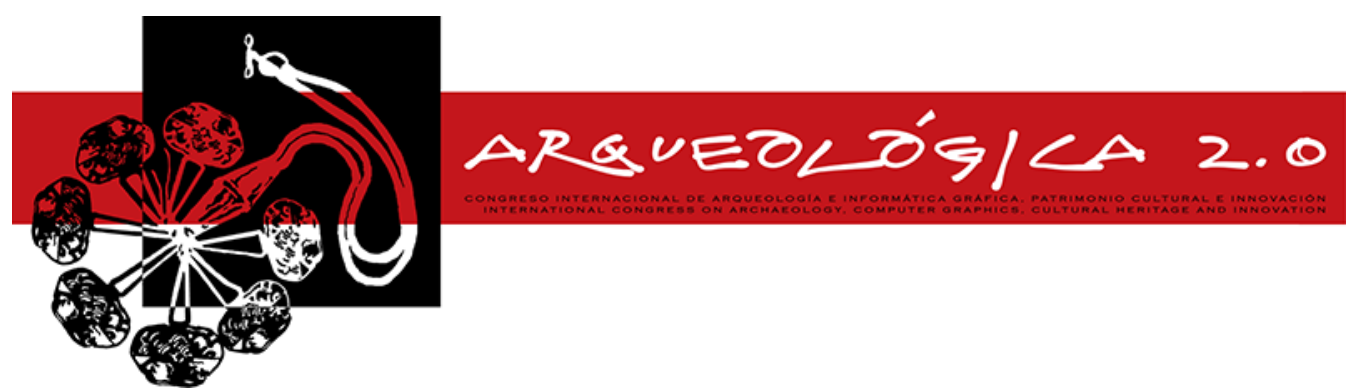

Proceedings of the $8^{\text {th }}$ International Congress on Archaeology, Computer Graphics, Cultural Heritage and Innovation

'ARQUEOLÓGICA 2.0'

in Valencia (Spain),

Sept. $5-7,2016$

DOI: http://dx.doi.org/10.4995/arqueologica8.2016.3262

\title{
A RECORDING AND DOCUMENTATION SYSTEM OF BUILDING STOCK: THE CASE OF PENTALOFOS SETTLEMENT IN KOZANI (GREECE)
}

\author{
Nikolaos Lianos, Anastasios Stamnas \\ Faculty of Architecture, Democritus University of Thrace, Greece. nlianos@arch.duth.gr
}

\begin{abstract}
:
Facing the need for effective and efficient integration of spatial and descriptive information related to the documentation of the cultural heritage, the primary aim of this project is the production of a dynamic geodatabase in order to collect, record and organize cartographic and architectural data as well as morphological and typological features of Pentalofos settlement into a GIS application. For this purpose, the project is meant, among other things, to complete a thorough research on the evolution of the settlement and its context, create the necessary geographic background for the documentation of the area of interest and to record building's technical features among others (year of construction, property status, structure, morphology, typology, description of current condition, pathology etc) by implementing traditional and up-to-date as well architectural documentation methods.
\end{abstract}

Key words: cultural heritage, documentation, GIS, laser scanning

\section{Introduction}

Innovative use of technology on the promotion of cultural information and cultural project management by applying exclusively new digital technologies, such as the internet, multimedia applications, three-dimensional computer graphics, virtual reality and Geographic Information System (GIS) applications, are nowadays objects of study for a significant number of scientists. Similar issues and problems are now addressed to a wide range of public, not only within the education and research community, but also to different professional specialties such as information technology, museology, media, history and archaeology, arts, architecture etc.

Applications of special scientific interest and the combination of different methods and techniques, such as laser scanning technology and GIS, act as a catalyst for the promotion and the management of cultural monuments and archaeological sites. Up-to-date methods and surveying equipment combined with the capabilities of GIS allow the processing of huge amount of data, acquired during the surveying and documentation process, and the creation of digital cultural heritage multimedia applications.

On the one hand, the creation of geographical index lists, dynamic maps and three-dimensional representations of cultural monuments as well, and, on the other hand, the detection of properties and the state of maintenance of monuments using the latest technology available, contribute decisively to reveal pathological causes and provide practical guidelines on rehabilitation interventions.

In this context, this project aims to exploit the potential of digital technologies by applying traditional and up-todate architectural documentation methods in order to create a recording and documentation system of building stock of Pentalofos settlement in Kozani (Fig. 1). Basis of this project was the systematic recording of a significant number of buildings during the past four "Workshops in the Conservation of Historical and Vernacular Architectural Buildings in Mastorochoria in the Prefecture of Kozani”, organized by the Laboratory of Architectural Theory of Forms and Preservation Studies, Faculty of Architecture, Democritus University of Thrace, in collaboration with the "Literature and Arts Association of Kozani Prefecture".

\section{Case study: Pentalofos settlement in Kozani}

\subsection{General information and brief history of the settlement}

Pentalofos settlement is part of Kozani regional unit, West Macedonia, Greece. It istands at about $1060 \mathrm{~m}$. a.s.I. at the foot of Voio Mountain (Fig. 2). Since the 2011 local government structural reform, Pentalofos is a municipal unit of the Voio Municipality and the population of the municipal unit for the year 2011 was 620 people.

“Corresponding Author: Nikolaos Lianos, nlianos@arch.duth.gr 
a)

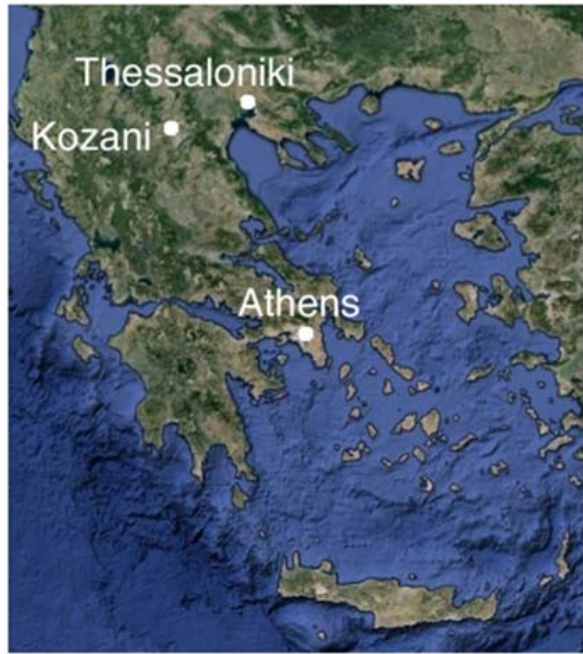

b)

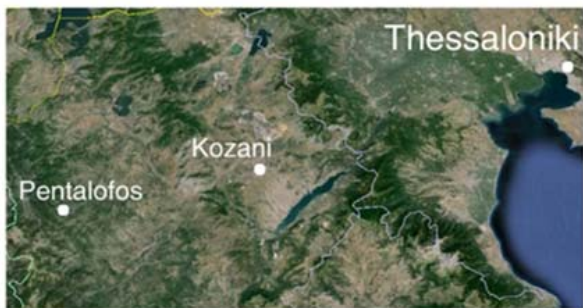

Figure 1: Map of Greece and the location of Kozani (a). The location of Pentalofos settlement (b) (Source: Gougle Earth).

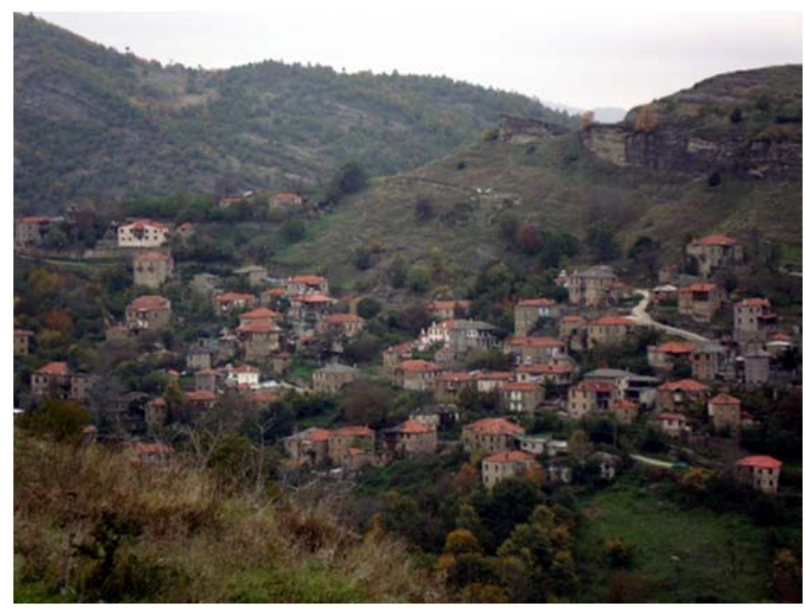

Figure 2: Panoramic view of Pentalofos (June 2014).

The first nuclei of Pentalofos settlement (Fig. 3) were formed about 1427 A.D. and then populated purely by Greek speakers from other regions of Voio and Epirus. During the Byzantine era and then the Othoman rule in Greece, the invasion by several barbaric tribes from the North continued: Celts, Gauls, Goths, Huns, Normans, Franks, Slavs and Bulgarians.

The province of Voio released and joined Greece in October 1912 A.D. During the Second World War, Pentalofos used to be a military base of the Greek army. From there, women of Pindos Mountains, loaded with ammunition, went ahead the war front and carried injured men on their return to the village. The village was bombed several times and then suffered the consequences of the Grrek Civil War. A period of poverty and abandonment followed while skilled stone and wood craftsmen migrated across and beyond Greece.

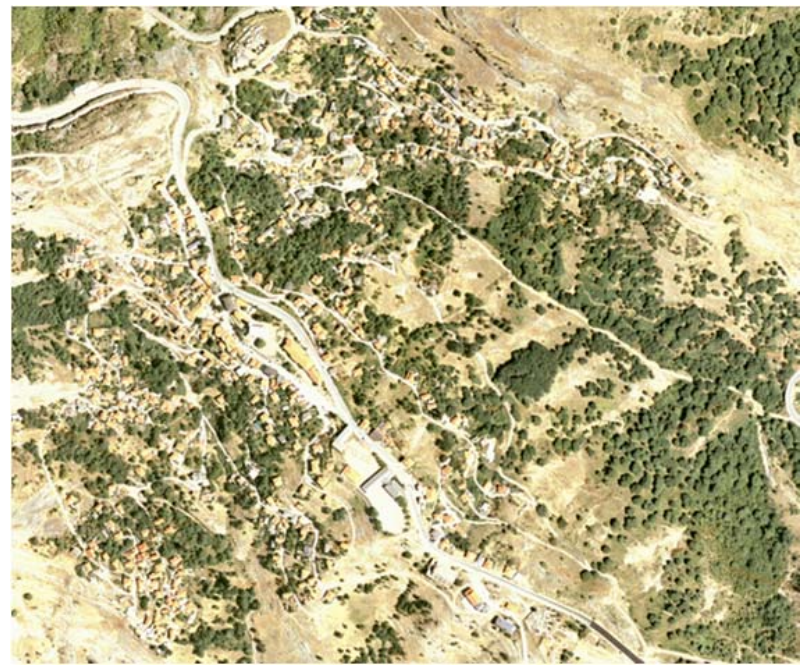

Figure 3: Aerial photo of Pentalofos (2007).

\subsection{Analysis of the settlement}

In order to understand and portray the structure of Pentalofos settlement, a large amount of data and systems, the historic settlement is comprised of, should be noted, systematically recorded and evaluated. This analysis includes the structure of neighborhoods and building plots, the organization of public and private open spaces, the arrangement of traffic network and grid road system, the system of land distribution, organization of building volumes and street fronts and the type and location of individual buildings contributing to the tissue of the village.

The systems of the urban tissue of Pentalofos settlement are as follows (Fig. 4): the system of building plots (a), the road system (b), the system of built-up and unbuilt areas (c) and the system of monuments and other significant buildings of the settlement (d).

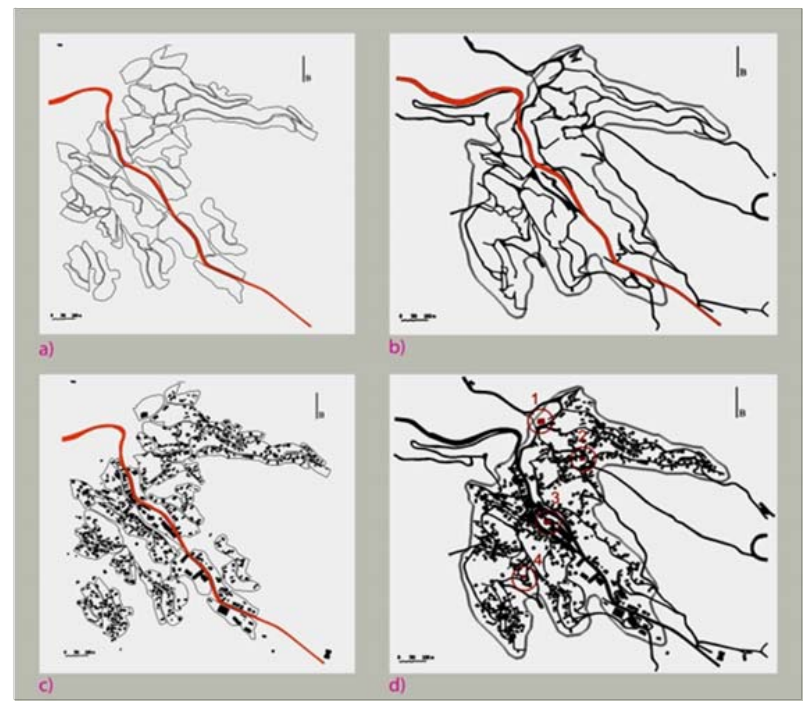

Figure 4: The structure of the urban tissue of Pentalofos. 
The arrangement of rural building plots of the settlement obeys mainly the natural geomorphologic characteristics (Fig. 5) and the natural development of the rural family as well, and it manifests as an element of diversity and picturesqueness of the vernacular architecture. The road system of the settlement is the result of extended configurations and illustrates in an obvious manner the relationships and the importance of linkages between the village and the surrounding area. In this configuration, both the topography and the location of the core functions of the settlement, the presence of significant elements of the built environment, such as religious and public buildings, have played a key role (Fig. 4d).

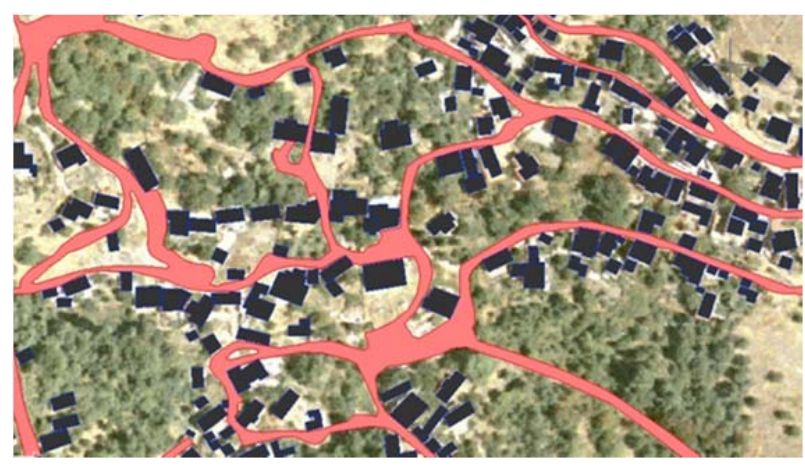

Figure 5: The system of roads and the structure of built-up areas of the down district of Pentalofos.

The system of built-up areas presents itself in varying degrees of continuity and discontinuity, arising from the location of buildings on the plot and the relations between them. Similarly, free unstructured areas are closely bound up with the built environment, as it is not possible to define a free area without comparing it with other structures. Therefore, the organization of unbuilt areas is expressed as the negative of built-up areas.

The whole number of monuments and significant buildings of the settlement represents isolated buildings and not a coherent system of buildings with a continuous form. Their presence (Fig. 6), however, is particularly important for the general structure of the settlement in spite of the changes and the transformations of their role and importance through the years.
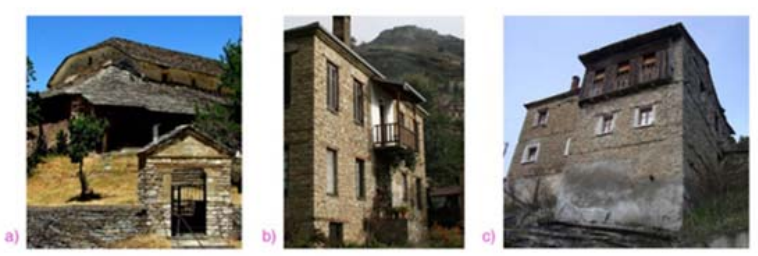

Figure 6: Saint Achilles church (a) and indicative buildings of the down district of Pentalofos (b) and (c).

\subsection{The importance of documentating the settlement}

Today, more than ever before, international committees that work for the protection of cultural heritage places such as the ICOMOS, a non-governmental international organisation dedicated to the conservation of the world's monuments and sites, or the International World Heritage Programme administered by the United Nations
Educational, Scientific and Cultural Organization (UNESCO) and charters presenting the general principles and doctrines relating to the protection of monuments such as the Athens Charter for the Restoration of Historic Monuments, adopted at the First International Congress of Architects and Technicians of Historic Monuments (Carta del Restauro, Athens 1931), the International Charter for the Conservation and Restoration of Monuments and Sites (The Venice Charter, 1964) and the Declaration of Amsterdam (The Congress of Amsterdam, 1975) express the opinion that the architectural heritage includes not only individual buildings of exceptional quality and their surroundings, but also all areas of towns or villages of historic or cultural interest.

In this context, the study of Pentalofos settlement is proposed as an instrument for the reading of its history, natural and cultural, for the understanding of its timeless progression and for the diagnosis of management perspectives towards sustainable development. For this purpose, the study is meant, among other things, to complete a thorough research on the evolution of the settlement and its context, create the necessary geographic background for the documentation of the area of interest and to record building's technical features among others (year of construction, property status, structure, morphology, typology, description of current condition, pathology etc) by applying traditional and up-to-date as well architectural documentation methods.

\section{Organizing a recording and documentation system of building stock of Pentalofos}

\subsection{Structure of the system}

The focus of this study was targeted towards, on the one hand, the production of the necessary cartographic background for the documentation of Pentalofos settlement (aerial photos and cartographic maps) and the creation of a dynamic geodatabase in order to collect, record and organizes architectural and technical features of its building stock, and on the other hand, the implementation of architectural documentation methods and the integration of all the above recordings and information of the settlement into a GIS application where all the geographic and thematic information can be stored, edited, integrated, analyzed and finally displayed in maps, each one of them portraying and highlighting a unique urban feature of Pentalofos settlement.

\subsection{Cartographic background and registration bulletins}

Aerial photos and cartographic maps (Fig. 7), provided by the Hellenic Military Geographical Service and the Lands and Mapping Service of Greece of The Ministry of Environment, were used as the necessary cartographic background for the recording, the analysis and the documentation of the settlement. After their geographical reference using the appropriate softwares (e.g. ERDAS Imagine), these maps gave a complete picture of the evolution of the settlement and its context through years. 


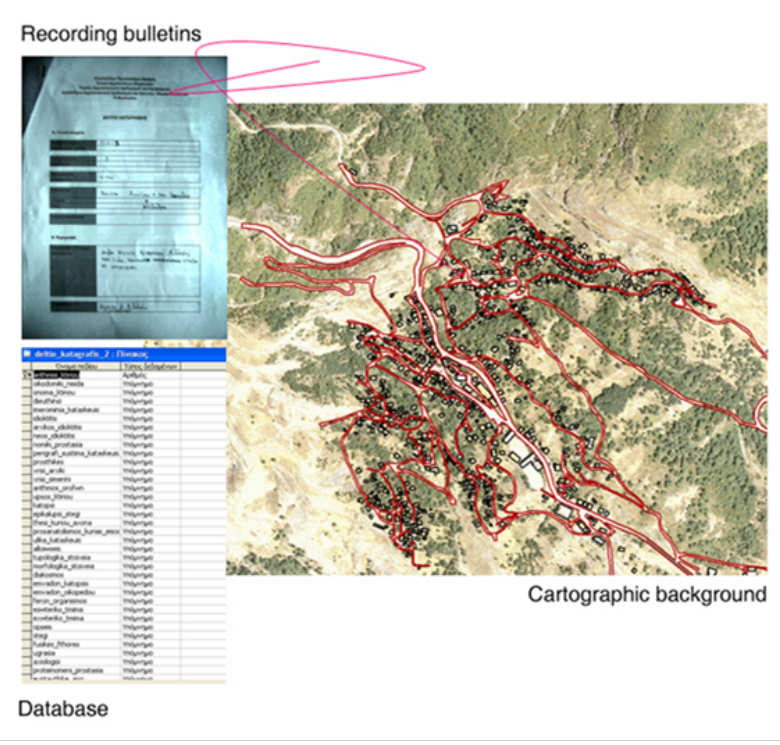

Figure 7: Cartographic background, registration bulletins and database used for the documentation of the building stock of Pentalofos settlement.

A thorough and systematic documentation of the building stock of Pentalofos was followed using registration bulletins (Fig. 7), specially designed for this purpose. As a result, a great number of important features of the buildings (total number: 38) were recorded. These features concern the chronology, the property, the morphology, the typology, the construction, the history and other information about the building stock of the settlement. For instance, these characteristics can de divided into two main groups:

A. The building code, the building plot, the building name, the region code, the construction date, the owner (original or new), the constitutional protection, the type of use (original or current) etc.

B. The construction system, the ground plan, the façades, the roof, the interior and the exterior parts, the number of floors, the total building height, the state of conservation, the protection grade etc.

Afterwards, all the features described above were properly and accurately organized and registered into a database (Fig. 7).

\subsection{Architectural documentation methods}

Heritage recording is the capturing of graphic and photographic information describing the physical configuration, evolution, and condition of a heritage place. Today, due to rapid technological development in the field of measured survey techniques, a broad range of recording techniques can be applied and the measured survey tool (or combination of tools) that will best match project requirements can be chosen. In this context, traditional and up-to-date as well architectural documentation methods were implemented in order to record the building stock of Pentalofos settlement. The three main types of documentation, applied for this purpose, were as follows:

A. Photographic documentation and detailed measured drawings.
B. Topographic and photogrammetric techniques.

C. 3D laser scanning techniques.

The first type of documentation involved baseline measurements (plans, roofs, cross sections and façades) and photographic recording of each building (Fig. 8). This procedure helped to get a preliminary understanding of the current condition of the buildings, the way they were built, their arrangement etc. Along with photographs, measured drawings were actually key components of the heritage record of the settlement. Their production, taken hand in hand with a series of dimensional, topographic, and structural analyses, was an indispensable part of the process of understanding the building stock of the settlement.

a)
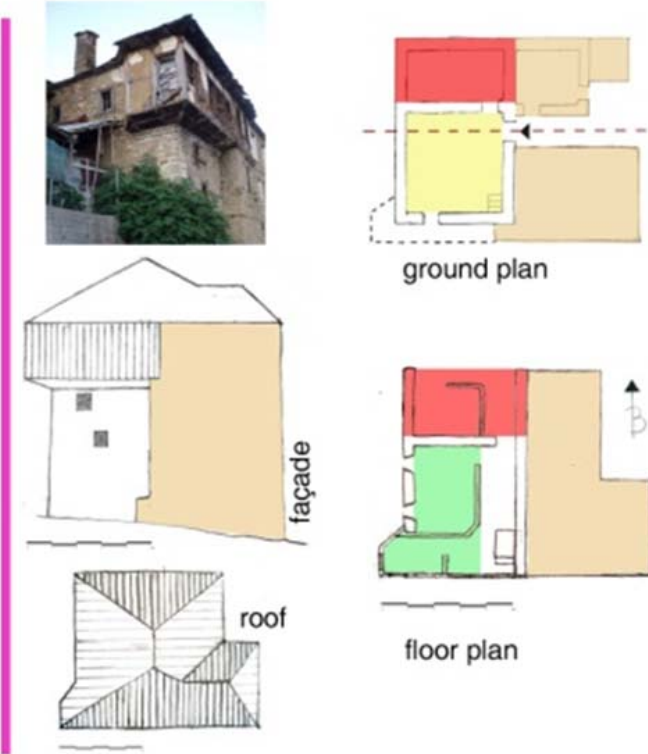

ground plan

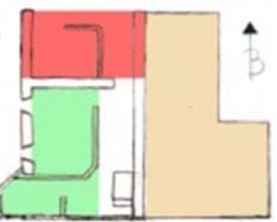

floor plan
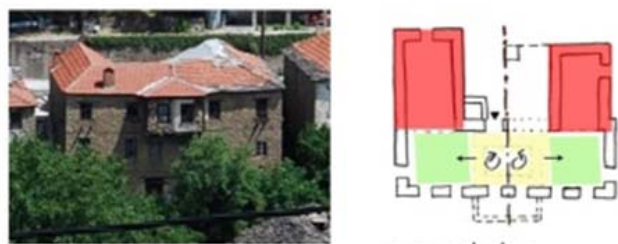

ground plan
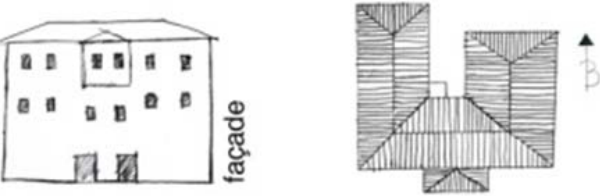

roo

b)

Figure 8: Photographic documentation and schematic drawings of three buildings of Pentalofos settlement.

Topographic and photogrammetric techniques were used as well for the documentation of a small number of selected buildings of the settlement. Control points were 
measured using survey instruments (total stations) and photogrammetric images were rectified and scaled in order to produce digital photographic base map of the building façades (Fig. 9).

The four byzantine monuments of the settlement, Saint Athanasius church (Fig. 10), Saint Achilles church, Saint George's church and Saint Barbara's church, were recorded using 3D laser scanning techniques that made it possible to create high-resolution $3-D$ models and accurate and reliable drawings of the monuments, such as plans, cross sections and façades.

The implementation of the above methods made it clear that, even though the work that is in direct contact with the object is crucial, new technologies, such as laser scanning, can better fulfill the requirement of documentation. In this regard, the correlation of manual measured drawings that have a clear advantage with mechanized methods, such as photogrammetry or laser scanning, clarifies most questions concerning the documentation of a monument.
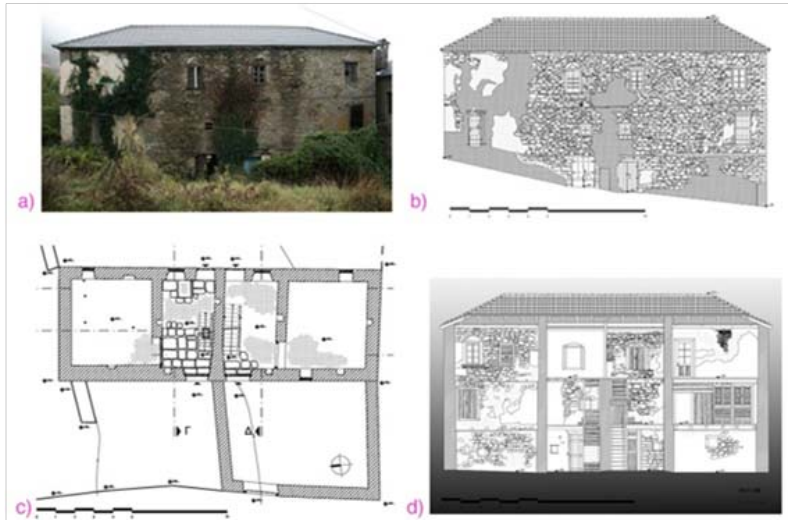

Figure 9: Photographic documentation: (a) and detailed drawings of a building, façade; (b) ground plan; (c) and cross section; (d) using topographic and photogrammetric techniques.

a)

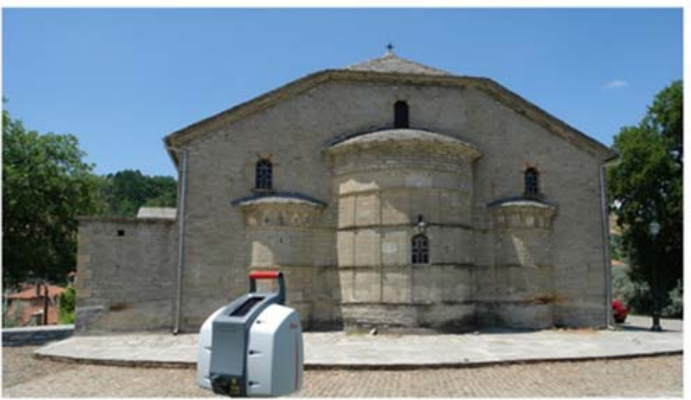

b)

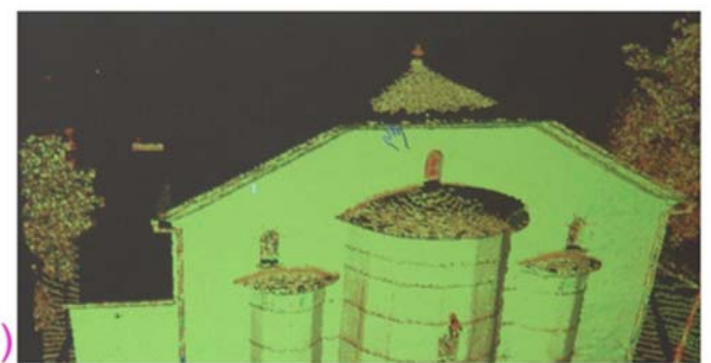

Figure 10: Laser Scanning: (a) and 3D data processing; (b) of Saint Athanasius church.

\subsection{GIS application}

This part of the project derives from the conjunction of the previous ones. It focuses on the creation of a geodatabase in which cartographic background, registration bulletins, drawings and documentation are related using a GIS application (Fig. 11). So all the above recordings and information of the settlement converge and join with the available spatial information of the area of interest.

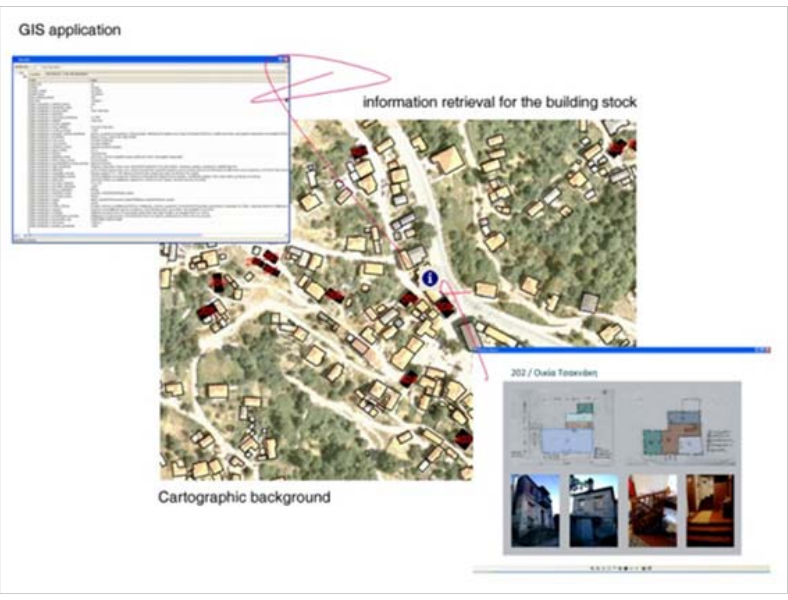

Figure 11: GIS application for the building stock of Pentalofos settlement.

The GIS can be described as a computer system capable of integrating, storing, editing, analyzing, displaying, and sharing geographically referenced information. In general, GIS applications are tools that allow users to create interactive queries, analyze spatial information, edit data, maps, and present the results of all these operations. In this case study, all the geographic information was stored, edited, integrated, analyzed and finally displayed in thematic maps. Appropriate data analysis and processing provided a significant number of thematic maps, each one portraying and highlighting the unique architectural, morphological and typological features of Pentalofos.

\section{Conclusions and future work}

The detailed recording of the architectural, morphological, typological, etc. characteristics of the building stock of Pentalofos settlement provided a better understanding of the examined heritage in terms of values, condition and relationship to the urban context.

Like all research activities, architectural survey needs careful project design and the choice of methodologies depends on case-specific factors. All recording operations must be carefully documented and the outputs (graphic representations, photographs, archival documentation etc) must be examined critically.

As far as the documentation of the building stock of Pentalofos is concerned, the integration of different techniques has proved to be indispensable. The GIS application for the record, analysis and documentation of the settlement played a key role in the whole project. Such a GIS application can be a useful tool for its institutional protection. Thus recording of the current situation of the settlement can be particularly useful as a substratum for restoration works. Alongside the detailed 
recording may help in further analysis and the export of many important findings concerning our cultural heritage.

\section{Acknowledgements}

We would like to express our sincere thanks and appreciation to those who attended the past four "Workshops in the Conservation of Historical and
Vernacular Architectural Buildings in Mastorochoria in the Prefecture of Kozani", organized by the Laboratory of Architectural Theory of Forms and Preservation Studies, Faculty of Architecture, Democritus University of Thrace, in collaboration with the "Literature and Arts Association of Kozani Prefecture" and helped with field measurements and data acquisition and processing as well.

\section{References}

AGAPIOU, A., GEORGOPOULOS, A., IOANNIDES, M. and IOANNIDIS, Ch., 2008. A Web Based GIS for the Byzantine Churches of Cyprus, Conference on Virtual Systems and MultiMedia Dedicated to Digital Heritage, Project Paper Volume pp. 148-151.

HADDAD N.A., 2011. From ground surveying to 3D laser scanner: A review of Techniques Used for Spatial Documentation of Historic Sites, Journal of King Saud University - Engineering Sciences, Volume 23, Issue, 2, pp. 109-118.

HERAS V., STEENBERGHEN T., ZÚÑIGA M., CARDOSO F., SANTANA M. and VAN BALEN K., 2012. An Information System for Heritage Documentation Management of Cuencacity, Ecuador, MASKANA, Revista semestral de DIUC, Vol. 3, No. 1.

LETELLIER R., SCHMID W. and LEBLANC F, 2007. Recording, Documentation, and Information Management for the Conservation of Heritage Places: Guiding Principles, The Getty Conservation Institute.

MAISTROU H. and PSYCHOGYIOS D., 2006. Presentation of an Integrated System for the Recording and Documentation of the Cultural Heritage of a Historic City. Digital Registry for the Historic Centre of Nafplion, The 7th International Symposium on Virtual Reality, Archeology and Cultural Heritage, VAST.

PAPPA K., GEORGOULA O., STAMOU A., STAMNAS A. and KAFKOULA K., 2009. Record, Analysis and Documentation Using GIS Applications for the Institutional Protection of Enoria Settlement in Greece, 22nd CIPA Symposium, Kyoto, Japan.

PATIAS P., STAMNAS A., GEORGIADIS CH., STYLIANIDIS E. and KAIMARIS D., 2011. Mapping of Buildings Facades' at the Historical Centre of Nicosia and Creating a Preservation Information System, XXIII CIPA Symposium, Prague, Czech Republic.

REMONDINO F., 2011. Heritage Recording and 3D Modeling with Photogrammetry and 3D Scanning. Remote Sensing 3(1), pp. 1104-1138, doi:10.3390/rs3061104. 